Bangladesh J. Bot. 49(3): 671-678, 2020 (September)

\title{
COMPARISON OF PHYSICOCHEMICAL AND ANTIOXIDANT PROPERTIES OF EDIBLE FRUITS IN THE SUNDARBANS' MANGROVE FOREST, BANGLADESH
}

\section{Zakir Hosen, Anirban Biswas, M Rabiul Islam, Mohammad Nazrul ISlam BhuiYan ${ }^{1}$ and Sheikh JUlfikar Hossain**}

\author{
Biotechnology and Genetic Engineering Discipline, Khulna University, \\ Khulna-9208, Bangladesh
}

Keywords: Antioxidant, Mangrove fruits, Nutrients, Polyphenols, Sundarbans

\begin{abstract}
Ten edible fruits of the Sunderbans' mangrove forest in Bangladesh were analyzed to compare their physicochemical, nutritional and antioxidant properties. Among the fruits, the lowest $\mathrm{pH}$ of 4.2 was observed in Sonneratia caseolaris whereas the rest remains within 6.1 to 7.1. The highest electrical conductivity (596.3 $\mu \mathrm{S} / \mathrm{cm})$, total dissolved solid $(298.2 \mathrm{ppm})$ and ash content $(0.26 \%)$ were recorded in the fruit of Phoenix paludosa. Carbohydrate, protein, lipid and vitamin C contents were the highest in Avicennia officinalis, Ceriops decandra, Heritiera fomes and Bruguiera gymnorrhiza fruits, respectively. In these fruits, the most abundant macro and micro-elements were $\mathrm{K}$ and Fe, respectively. $C$. decandra showed the highest content of polyphenols (58.5 mg GAE, gallic acid equivalent/g powder), flavonoids (86.4 mg CE, (+)-catechin equivalent/g powder) and anthocyanins $(0.39 \mu \mathrm{mol} / \mathrm{g}$ powder $)$. $C$. decandra also showed the strongest DPPH free radicals scavenging, reducing power, and total antioxidant capacity. Noticeably, total polyphenols showed their strong correlation to total flavonoids $\left(r^{2}=0.90\right)$, anthocyanins $\left(r^{2}=0.81\right)$, reducing power $\left(r^{2}=\right.$ $0.98)$ and total antioxidant capacity $\left(\mathrm{r}^{2}=0.88\right)$ of the fruits. Fruits of $C$. decandra, therefore, should be considered as a potential source of antioxidants followed by $H$. fomes and $P$. paludosa.
\end{abstract}

\section{Introduction}

The Sundarbans' is the single largest contiguous tracts of mangrove forest in the world which is situated in the South-Western region of Bangladesh. Among the edible fruits in the Sundarbans', S. apetala is consumed largely in coastal areas in Bangladesh followed by $S$. caseolaris and $N$. fruticans. Previous reports showed polyphenols, flavonoids and anthocyanins contents, nutrient compositions, antioxidant, antibacterial, antidiabetic, antidiarrheal, analgesic and cytotoxic activities in S. apetala fruit (Hossain et al. 2013, 2016, 2017). Hossain et al. (2013, 2016) recommended that $S$. apetala fruits should be cultivated in the tidal sea-water intruded vast tropical coastal regions of the world for the purposes of food security, primary health care, environmental protection, income generation and for preparing functional foods or dietary supplements. Fruits of S. caseolaris are also popular, and non-toxic (Chen et al. 2009), soft in texture having specific flavors, and good taste, and thus various food products, such as syrup (Abeywickrama and Jayasooriya 2010), cakes and steamed pudding (Brown 2006) have been produced from it. Brown (2006) also reported the preparation of different recipes using the fruits of Avicennia sp., N. fruticans, B. gymnorrhiza etc. People adjacent to the Sundarbans' also largely consume the inner endosperm of $N$. fruticans. Prasad et al. (2013) evaluated phenolics and antioxidant in endosperms of $N$. fruticans. Fruits of $P$. paludosa are eaten to some extent, and reportedly, they are used as a coffee substitute.

*Author for correspondence: <sjhossain_ku@yahoo.com>; <sjhossainbgeku@gmail.com>. ${ }^{1}$ Institute of Food Science and Technology, Bangladesh Council of Scientific and Industrial Research (BCSIR), Dhanmondi, Dhaka-1205, Bangladesh. 
However, little scientific attention on the edible fruits of the Sundarbans' mangrove forest has been paid till today. Edible fruits in the Sundarbans' are important resources with an untapped potential, and therefore, the current study was undertaken.

\section{Materials and Methods}

Edible fruits of Aegiceras corniculatum (L.) Blanco., Avicennia officinalis L., Bruguiera gymnorrhiza (L.) Lamk., Ceriops decandra (Griff.) Ding Hou, Heritiera fomes Buch.-Ham., Nypa fruticans Wurmb., Phoenix paludosa Roxb., Sarcolobus globosus Wall., Sonneratia caseolaris (L.) Engl., and Xylocarpus mekongensis Pierre were collected from the Sundarbans' mangrove forest, Bangladesh from July to September, 2017. Each dried fruit was pulverized into fine powder with the help of a grinder machine and stored for chemical analysis at room temperature.

Ten grams of powder of each fruit was taken in a separate airtight bottle. Then, $200 \mathrm{ml}$ of methanol and ethanol mixture $(1: 1)$ was added to each bottle. The mixtures were vigorously shaken, and kept overnight at $30^{\circ} \mathrm{C}, 150 \mathrm{rpm}$. After $20 \mathrm{hrs}$, the mixtures were filtered through Whatman No. 1 filter paper. The filtrates were then air dried, and after adjustment of volumes, the extracts were kept in a refrigerator at $4^{\circ} \mathrm{C}$.

Average fresh weight, diameter, and length of the fruits were measured $(\mathrm{n}=\sim 50)$. The $\mathrm{pH}$ of the fruits was determined using a pH meter. Electrical conductivity (EC) and total dissolved solid (TDS) were measured through EC meter. The ash, free acidity, moisture, carbohydrate, protein, lipid and vitamin C were also determined using standard methods (AOAC 1995). Mineral contents in the fruits were estimated as described by Hoenig and de Kersabiec (1996). Na and K in digested powders were determined flame photometerically and that of $\mathrm{P}$ was quantified by UVvisible spectrophotometric method.

The total concentration of polyphenols (TPH) in the extracts was determined according to the Folin-Ciocalteu method (Ough and Amerine 1988) with gallic acid (GA) as the standard. The total flavonoid content (Zhishen et al. 1999), total anthocyanin content (Padmavati et al. 1997), DPPH free radicals scavenging activity (Blois 1958), reducing power (Oyaizu 1986) and total antioxidant capacity (Prieto et al. 1999) were determined in the extract.

Results were expressed as mean of observations, $n=3-50$. One way analysis of variance followed by LSD multiple comparison post-hoc test was used. Differences with $\mathrm{p}$ values $<0.05$ were considered statistically significant.

\section{Results and Discussion}

The average fresh weight, diameter, length, $\mathrm{pH}, \mathrm{EC}$, TDS, ash, free acidity, and moisture of the fruits ranged from 0.6 to $83.7 \mathrm{~g}, 0.4$ to $5.1 \mathrm{~cm}, 1.4$ to $12.3 \mathrm{~cm}, 4.2$ to $7.1,277.9$ to 596.3 $\mu \mathrm{S} / \mathrm{cm}, 138.5$ to $298.2 \mathrm{ppm}, 0.08$ to $0.26 \%, 11.5$ to $85.8 \mathrm{meq} / \mathrm{kg}$, and 42.5 to $91.3 \%$, respectively (Table 1). Carbohydrate content was the highest in the fruit of A. officinalis (49.8\%) followed by $N$. fruticans $(32.5 \%)$. Protein content was the highest in $C$. decandra $(19.1 \%)$ followed by $H$. fomes $(18.6 \%)$. Lipid and vitamin C contents ranged from 0.5 to $3.1 \%$ and 55.6 to $114.1 \mathrm{mg}$ ascorbic acid, AA/100 g powder, respectively (Table 2). No toxic element $(\mathrm{Cd}, \mathrm{Co}, \mathrm{Cr}, \mathrm{Ni}$ or $\mathrm{Pb}$ ) was found in these fruits. Among the macroelements, $\mathrm{K}$ was the most abundant followed by Na, P, $\mathrm{Mg}, \mathrm{Ca}$ whereas in microelements Fe topped all followed by $\mathrm{Zn}, \mathrm{Cu}$ and $\mathrm{Mn}$ (Table 2). Hence, these fruits have potentiality to be used as nutritional supplements for coastal people suffering from malnutrition. Nutritional and health promoting properties of the fruit, S. apetala (Hossain et al. 2013, 2016, 2017) from the Sundarbans' have also been reported.

The highest content of polyphenols, flavonoids and anthocyanins were recorded in $C$. decandra followed by $H$. fomes and $P$. paludosa (Table 3 ). The cause of relatively higher amount 


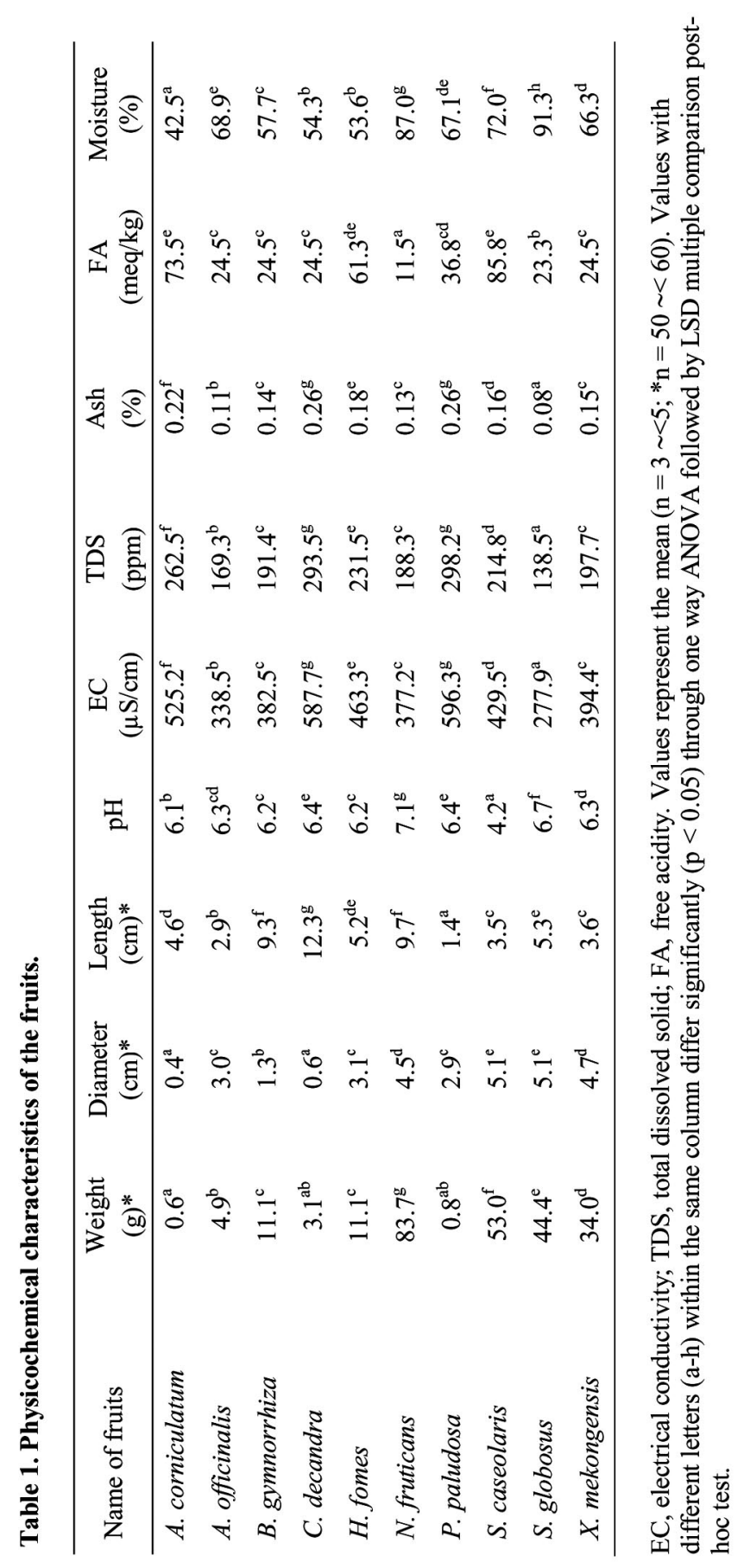




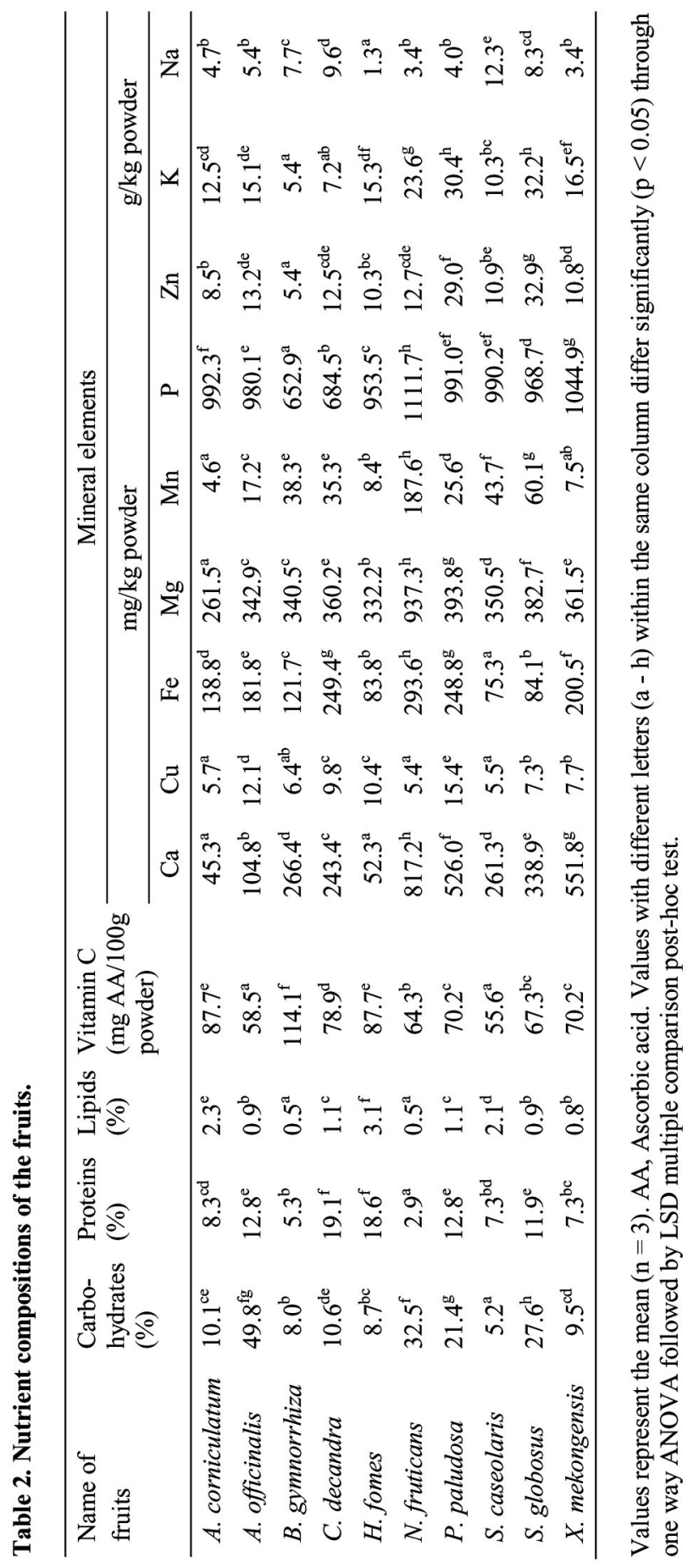




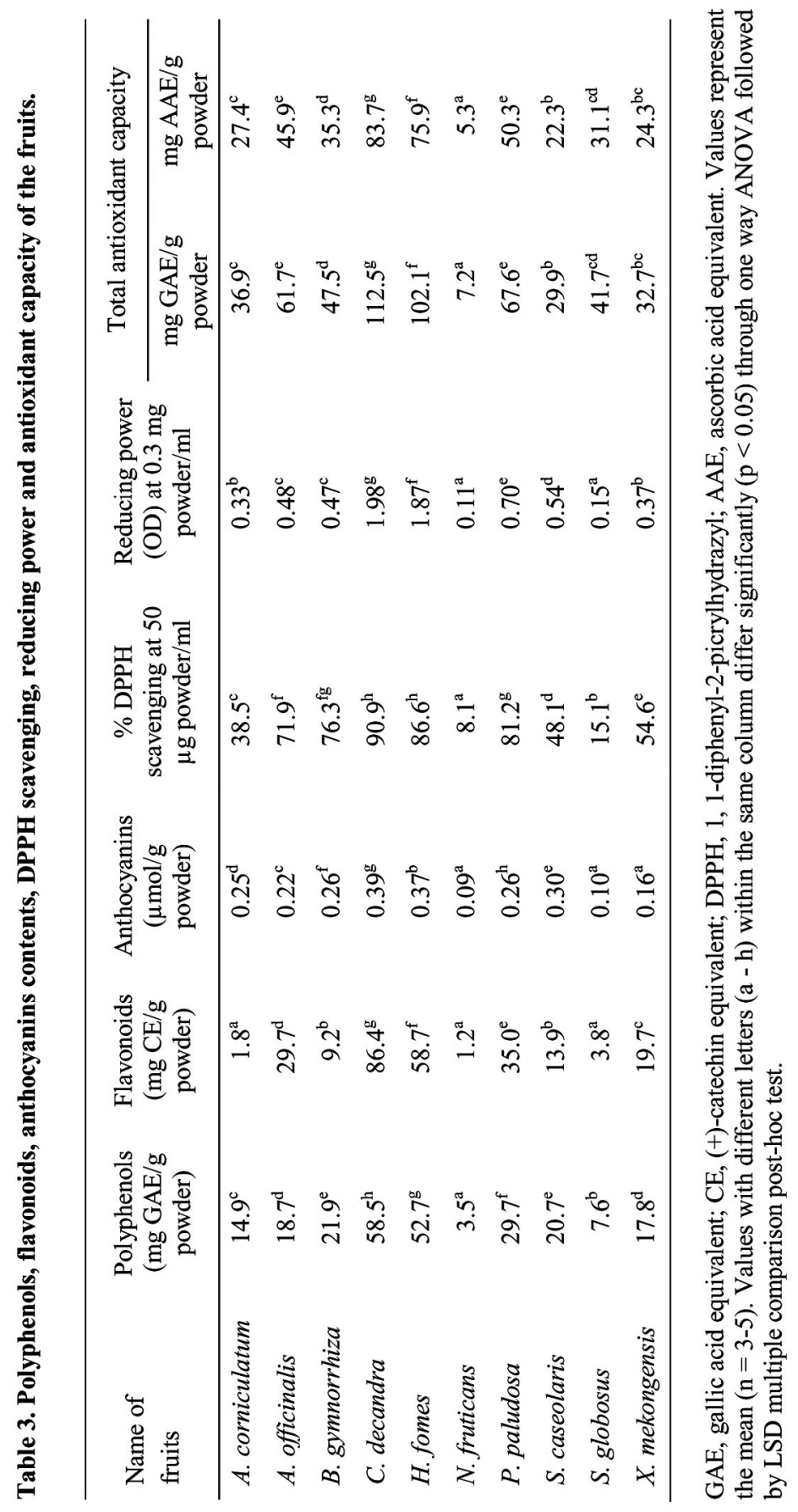



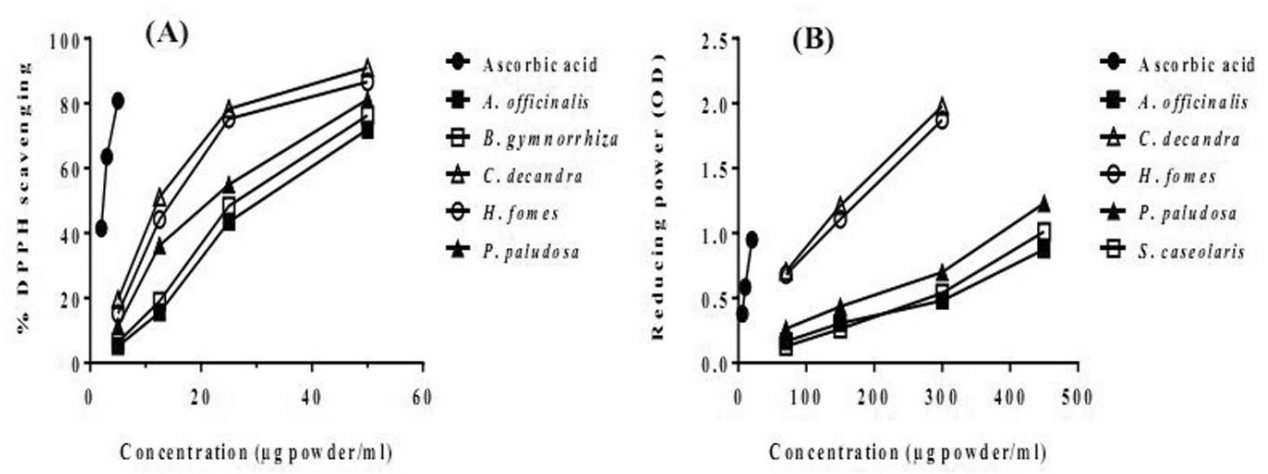

Fig.1. Dose-dependent (A) DPPH free radical scavenging activity and (B) increase of reducing power of the potential fruits.
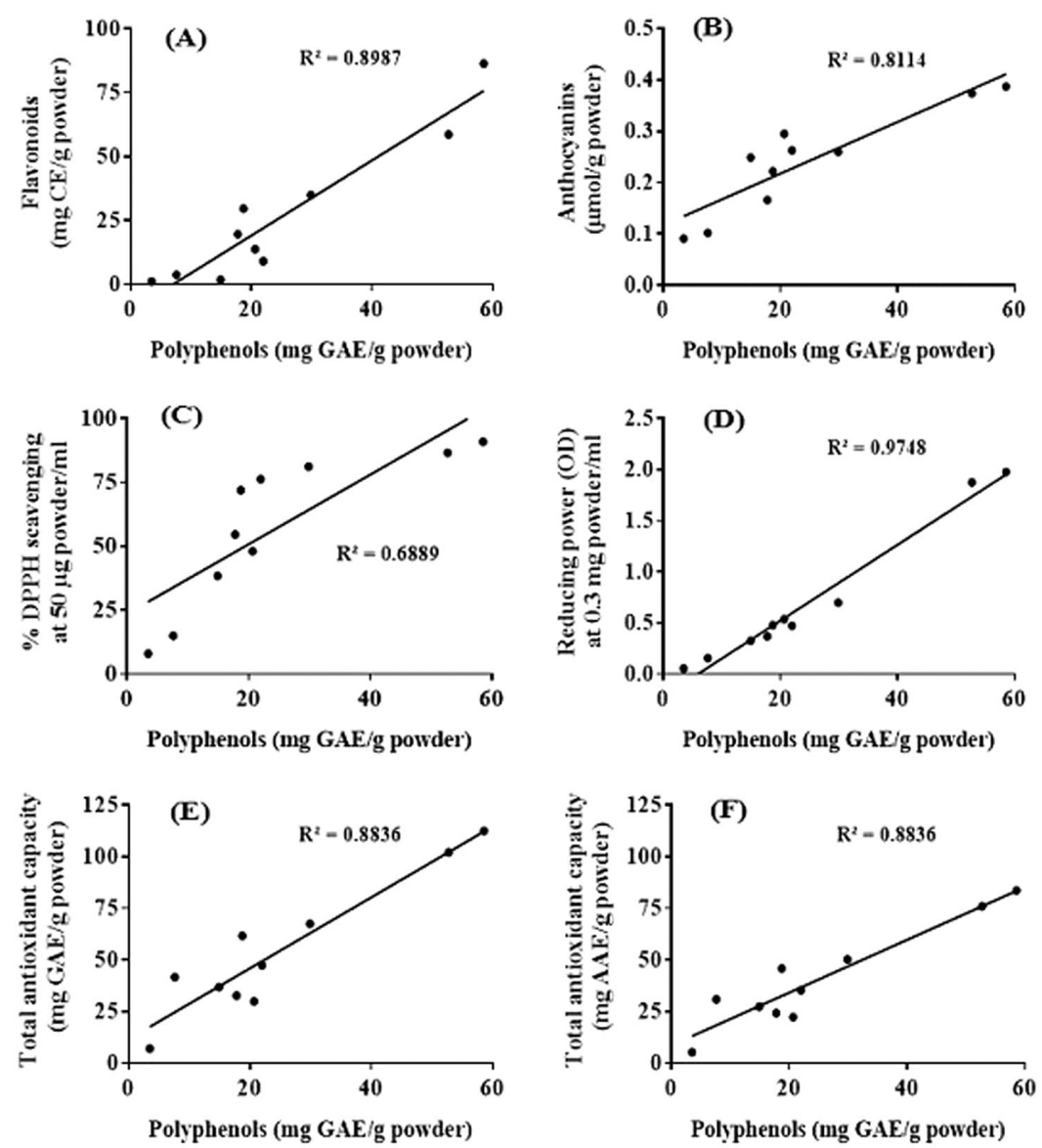

Fig. 2. Correlation of polyphenols to (A) flavonoids, (B) anthocyanins, (C) DPPH scavenging, (D) reducing power, (E) total antioxidant capacity (mg GAE) and (F) total antioxidant capacity (mg AAE) of the fruits. $\mathrm{GAE}$, gallic acid equivalent and $\mathrm{AAE}$, ascorbic acid equivalent. 
of recorded total flavonoids than total phenolics in some fruits might be due to inefficiency of Folin-Ciocalteu method. The percentage scavenging of DPPH free radical ranged from 8.1 to $90.9 \%$ at $50 \mu \mathrm{g}$ powder/ml. Dose-dependent DPPH free radical scavenging activities of A. officinalis, B. gymnorrhiza, $C$. decandra, $H$. fomes and $P$. paludosa showed that $C$. decandra possessed the strongest activity with the lowest $\mathrm{IC}_{50}$ value of $16.2 \mu \mathrm{g}$ powder $/ \mathrm{ml}$, which was little larger than ascorbic acid $\left(\mathrm{IC}_{50} 2.4 \mu \mathrm{g} / \mathrm{ml}\right)$ followed by $H$. fomes $(19.5 \mu \mathrm{g}$ powder $/ \mathrm{ml}), P$. paludosa (26 $\mu \mathrm{g}$ powder $/ \mathrm{ml})$, B. gymnorrhiza $(31.1 \mu \mathrm{g}$ powder $/ \mathrm{ml})$ and A. officinalis $(33.7 \mu \mathrm{g}$ powder $/ \mathrm{ml})$ (Fig. 1A). The $\mathrm{IC}_{50}$ values for DPPH free radical scavenging for common edible fruits (Hossain et al. 2008), fruity vegetables (Hossain et al. 2014) and leafy vegetables (Hossain et al. 2015) were also reported. At $300 \mu \mathrm{g}$ powder $/ \mathrm{ml}$ concentration, $C$. decandra had the highest absorbance (OD 1.98) followed by H. fomes (OD 1.87), P. paludosa (OD 0.7) etc. They showed dose-dependent increase in their reducing power (Fig. 1B). It may be due to high content of polyphenols as well as hydrogen donating ability. $C$. decandra showed the highest total antioxidant capacity $(112.5 \mathrm{mg}$ GAE/g powder; $83.7 \mathrm{mg} \mathrm{AAE} / \mathrm{g}$ powder) followed by $H$. fomes $(102.1 \mathrm{mg} \mathrm{GAE} / \mathrm{g}$ powder; $76 \mathrm{mg}$ AAE/g powder) and $P$. paludosa (67.6 $\mathrm{mg}$ GAE/g powder; $50.3 \mathrm{mg}$ AAE/g powder).

Total polyphenols and total flavonoids showed strong correlation $\left(\mathrm{r}^{2}=0.90\right)$, and so did total polyphenols and anthocyanins $\left(\mathrm{r}^{2}=0.81\right)$, reducing power $\left(\mathrm{r}^{2}=0.98\right)$ also total antioxidant capacity $\left(r^{2}=0.88\right)$. However, moderate correlation $\left(r^{2}=0.69\right)$ was found between total polyphenols and DPPH free radical scavenging (Fig. 2). This moderate correlation may be due to the fact that only phenolics with a certain structure and with hydroxyl groups at specific positions can show radical scavenging activity (Nguelefack et al. 2011). Since some polyphenols nonspecifically bind with membrane structure, and perturb it (Hossain et al. 2002), clarification of proper dose of polyphenols is essential before using them for the preparation of dietary supplements, and functional foods. Among the ten edible fruits in the Sundarbans', $C$. decandra could be considered to be the best source of functional components, and antioxidants followed by $H$. fomes and P. paludosa.

\section{Acknowledgments}

The work was supported by the Grant no. 6(75)/Bio-36/2015 from the University Grant Commission of Bangladesh is gratefully acknowledged.

\section{References}

Abeywickrama WSS and Jayasooriya MCN 2010. Formulation and quality evaluation of cordial based on Kirala (Sonneratia caseolaris) fruit. Trop. Agric. Res. Exten. 13: 16-18.

AOAC 1995. Official methods of analysis 16th ed. Association of official analytical chemists. Washington DC, USA.

Blois MS 1958. Antioxidant determinations by the use of a stable free radical. Nature 181: 1199-1200.

Brown B. 2006. Cooking with mangroves: 36 Indonesian mangrove recipes. Mangrove Action ProjectIndonesia, pp. 1-44.

Chen L, Zan Q, Li M, Shen J and Liao W 2009. Litter dynamics and forest structure of the introduced Sonneratia caseolaris mangrove forest in Shenzhen, China. Est. Coast Shelf Sci. 85: 241-246.

Hoenig M and de Kersabiec AM 1996. Sample preparation steps for analysis by atomic absorption spectroscopy methods: present status. Spectrochim. Acta Part B: Atom. Spectrosc. 51: 1297-1307.

Hossain SJ, Basar MH, Rokeya B, Arif KMT, Sultana MS and Rahman MH 2013. Evaluation of antioxidant, antidiabetic and antibacterial activities of the fruit of Sonneratia apetala (Buch.-Ham.). Orient. Pharm. Exp. Med. 13: 95-102. 
Hossain SJ, Iftekharuzzaman M, Haque MA, Saha B, Moniruzzaman M, Rahman MM and Hossain H 2016. Nutrient compositions, antioxidant activity and common phenolics of Sonneratia apetala (Buch.-Ham.) fruit. Int. J. Food Prop. 19: 1080-1092.

Hossain SJ, Islam MR, Pervin T, Iftekharuzzaman M, Hamdi OAA, Mubassara S, Saifuzzaman M and Shilpi JA 2017. Antibacterial, antidiarrhoeal, analgesic, cytotoxic activities and GC-MS profiling of Sonneratia apetala (Buch.-Ham.) seed. Prev. Nutr. Food Sci. 22: 157-165.

Hossain SJ, Kato H, Aoshima H, Yokoyama Y, Yamada M and Hara Y 2002. Polyphenol-induced inhibition of the response of $\mathrm{Na}^{+} /$Glucose cotransporter expressed in Xenopus Oocytes. J. Agric. Food Chem. 50: 5215-5219.

Hossain SJ, Sultana MS, Iftekharuzzaman M, Hossain SA and Taleb MA 2015. A comparative study on antioxidant potential of common leafy vegetables in Bangladesh. Bangladesh J. Bot. 44: 51-57.

Hossain SJ, Sultana MS, Taleb MA, Basar MH, Sarower MG and Hossain SA 2014. Antioxidant activity of ethanol and lipophilic extracts of common fruity vegetables in Bangladesh. Int. J. Food Prop. 17: 20892099.

Hossain SJ, Tsujiyama I, Takasugi M, Islam MA, Biswas RS and Aoshima H 2008. Total phenolic content, antioxidative, anti-amylase, anti-glucosidase, and antihistamine release activities of Bangladeshi fruits. Food Sci. Technol. Res. 14: 261-268.

Nguelefack TB, Mbakam FHK, Tapondjou LA, Watcho P, Nguelefack-Mbuyo EP, Ponou BK, Kamanyi A and Park HJ 2011. A dimeric triterpenoid glycoside and flavonoid glycosides with free radicalscavenging activity isolated from Rubus rigidus var. Camerunensis. Arch. Pharm. Res. 34: 543-550.

Ough CS and Amerine MA 1988. Methods for analysis of musts and wine. Wiley \& Sons, New York, pp. 196-221.

Oyaizu M 1986. Studies on products of browning reaction: Antioxidative activity of products of browning reaction prepared from glucosamine. Jpn. J. Nutr. 44: 307-315.

Padmavati M, Sakthivel N, Thara KV and Reddy AR 1997. Differential sensitivity of rice pathogens to growth inhibition by flavonoids. Phytochem. 46: 449-502.

Prasad N, Yang B, Kong KW, Khoo HE, Sun J, Azlan A, Ismail A, Romli ZB 2013. Phytochemicals and antioxidant capacity from Nypa fruticans Wurmb. Fruit. Evid. Based Complement. Alternat. Med. ID 154606.

Prieto P, Pineda M and Aguilar M 1999. Spectrophotometric quantitation of antioxidant capacity through the formation a phosphomolybdenum complex: specific application to the determination of vitamin E. Anal. Biochem. 269: 337-341.

Zhishen J, Mengcheng T and Jianming W 1999. The determination of flavonoid contents in mulberry and their scavenging effects on superoxide radicals. Food Chem. 64: 555-559. 